\title{
THE COMPUTER-GENERATED ARTWORKS OF VLADIMIR BONAČIĆ
}

\author{
Darko Fritz \\ Multimedia artist, curator and researcher \\ Transart Institute \\ http://darkofritz.net/ \\ info@darkofritz.net
}

Scientist Vladimir Bonačić began his artistic career 1968 under the auspices of the international movement NewTendencies (NT), at the Gallery for Contemporary Art of Zagreb, which had pushed for his inclusion. From 1968 to 1971 Bonačić created a series of "dynamic objects" - interactive computer-generated light installations, five of which were set up in public spaces. The author shows the context of Bonačić's work within the Zagreb cultural environment dominated by the New Tendencies movement and network (19611973). The paper shows his theoretical and practical criticism of the use of randomness in computer-generated art and describes his working methods as combining the algebra of Galois fields and an anti-commercial approach with custom-made hardware. It seems that Bonačić's work fulfills and develops Matko Mestrovic"s proposition that "in order to enrich that which is human, art must start to penetrate the extra-poetic and the extrahuman."

\section{INTRODUCTION}

Vladimir Bonačić (1938-1999) worked at the Croatian national research center Ruđer Bošković Institute in Zagreb from 1962 to 1973. There, he headed the Laboratory for Cybernetics from 1969 to 1973 . He earned his Ph.D. in 1968 in the field of pattern recognition.[1] Vladimir Bonačić's artistic path is inseparable from the New Tendencies international movement and its established world view regarding the synergy of science and art.

The Galerija suvremene umjetnosti [Gallery of Contemporary Art] organized five New Tendencies exhibitions in Zagreb from 1961 to 1973; in addition, international exhibitions were held in Paris, Venice, and Leverkusen, West Germany. A group exhibition of European artists in 1961 grew into an international movement that would be referred to as "NT". NT act as a gathering place of artists, gallery owners, and theoreticians during the Cold War, first from Eastern and Western Europe and South America, and, from 1965 onwards, also from the USA, the Soviet Union, and Japan. 


\section{CAT 2010 London Conference $\sim 3^{\text {rd }}$ February \\ Darko Fritz}

Such a unique situation was realized by the cultural and geopolitical position of Zagreb, in the then socialist and non-aligned Yugoslavia.

In the catalogue of the first New Tendencies exhibition in 1961, the artist François Morellet, member of the Paris-based Groupe de Recherche d'Art Visuel [Visual Art Research Group] wrote: "We are on the eve of a revolution in art which will be just as large as the one in the field of science. Therefore, common sense and the spirit of systematic research need to replace intuition and individualistic expression.'”[2]

Further New Tenencies ideas - that can be completely applied to Bonačić's work - were presented 1963 in the catalogue of the second New Tendencies exhibition in a text by the Croatian art critic, theoretician, and co-founder of the New Tendencies movement, Matko Meštrović. The text was later revealingly republished under the title "Ideologija novih tendencija" [The Ideology of the New Tendencies], which it surely is according to its programmatic and theoretical structure.[3] The demythologization of art and demystification of the creative process were also proclaimed through a positive approach to the industrial production of works of art (the possibility of multiplication was essential), collective work, and a rational approach.

Meštrović called for speeding up the evolution and synthesis of science and art, within the framework of rendering humanities and art more scientific, as part of the long-term utopian process of the overall rendering of all human activity into science. Meštrović considered that this process can be actively started within the framework of art immediately, ditto for the display of a global model, striving to act in the sphere of culture using a smaller scale, e.g., through the appropriation of scientific methods, such as the experiment. The problems of scheduling all material and spiritual goods in equal measure and the return of scientific results into the public domain emerge. Meštrović did not consider artworks as unique goods for the artistic market, but as: "plastic-visual research, with the aim of determining the objective psychophysical bases of the plastic phenomenon and visual perception, in this way a priori excluding any possibility of including subjectivism, individualism, and romanticism [...]" [4]

Further, the thesis on the final surpassing of art as we know it was developed, through developing the conscience of the world using a metamorphosis of the social into the artistic act, which actively transforms the whole world.[5] We can trace such developments in practices of numerous New Tendenies artists and researchers in the early 1960s forming the context for the inclusion of scientists-artists such as Bonačić later on.

During the first half of the 1960s, the New Tendencies attained notable international reputation as a leading international platform of avant-garde of visual art that preferred rationality, social engagement, and interactivity with the user, which was achieved 


\section{CAT 2010 London Conference $\sim 3^{\text {rd }}$ February \\ Darko Fritz}

through scientific experimentation methodology and algorithmic programming of visual elements in the execution of objects, as well as environments made of industrial materials, movement, and light. While, in Matko Meštrović's words, "artists at the beginning of the movement intuitively strived towards science", often lacking a notion of what it implied,"[6] this situation radically changed in 1968 when the program Kompjuteri i vizuelna istraživanja/Computers and Visual Research started and a larger number of scientists began to actively participate in the New Tendencies.

In the conferences and exhibitions which were part of the program, a number of scholars, who left the realm of pragmatic scholarly work by creatively using computers, participated along with the artists.

The art critic Radoslav Putar noted and explained that gradual shift of forces within the New Tendencies in his preface to the 1968/1969 exhibition catalogue for Tendencije 4 [Tendencies 4]: "[...] many followers of the NT have tried to give their work the habit of the machine, or else they have based their procedures on the use of mechanical or electric devices; they have all dreamt of machines - and now the machines have arrived. And they have arrived from a direction which was somewhat unexpected and accompanied by people who were neither painters nor sculptors."[7]

Vladimir Bonačić, who actively participated in all parts of Computers and Visual Research within the Tendencije 4 during that short and obviously intense period, along with his scholarly work at the Ruđer Bošković Institute in Zagreb, started and realized a wide range of artworks, simultaneously developing its theoretical elaboration. Bonačić participated in both conferences related to Computers and Visual Research - the colloquy in 1968 and the symposium in 1969, the papers of which were published in the bit international journal that was launched by the Galerije suvremene umjetnosti in 1968.[8] Within the two exhibitions of 1968 and 1969, Bonačić displayed one joint work, created together with the artist and designer Ivan Picelj, as well as 21 individual works. In addition he presented a large, 36-meter computer-controlled light installation, DIN PR 18, in public space.

\section{JOINING THE NEW TENDENCIES}

During the preparation of Tendencije 4, organizers from the Galerija suvremene umjetnosti sought collaborators at the Ruđer Bošković Institute in Zagreb. Alongside other scientists who were to take part in the symposia, New Tendencies organizers met at the institute the young scientist Bonačić at the Ruđer Bošković Institute, who used visual research in his scientific work. Also at this time, Ivan Picelj, New Tendencies primary graphic designer, was asked to design the poster for the Tendencije 4 events. He decided to use punch cards of the institute's computer for a collage. Picelj then had 


\section{CAT 2010 London Conference $\sim 3^{\text {rd }}$ February \\ Darko Fritz}

the idea to take his work a step further and to produce a light object following his Površina [Surface] series of reliefs in wood and bronze, which he had been developing since 1961.

Here, Vladimir Bonačić entered the scene, and they began the collaboration that resulted in the electronic object entitled t4, the abbreviation of Tendencije 4. It was presented in 1969. The front panel of the object is made of a grid of round aluminum tubes, each holding a small light bulb. Each tube is cut at an angle. The upper part displays the characters "t4t4t4t4," animated to move from left to right and in several similar animations. The rest of the panel lights up asymmetric light patterns, and four knobs on the back of the object allowed for certain manipulations. Bonačić's experience in physics and electronics helped a great deal, as did the excellent production conditions in the workshops of the Ruđer Bošković Institute.

The first exhibition of computer graphics during the Colloquy at the Centar za kulturu $\mathrm{i}$ informacije [Centre for Culture and Information] in 1968 contained eight of Bonačić's computer-generated pictures titled RB 1-8, whereby "RB" denotes the place where the works were created, the Ruđer Bošković Institute, and the numbers are just markings that help distinguish the exhibits. All the exhibited works were photo reproductions of oscilloscope screenshots in different formats. The oscilloscope was an integral part of a self-constructed light-pen system linked with a PDP-8 computer. The programming language in use was "Assembler." One work marked as RB-9, depicts a figuratively outlined female figure while other works are abstract. A computer drawing of the human figure in the work RB-9, an experiment finally not publicly presented, questioning author's repeatedly stressed desire to create "something that has not yet been done" by using the computer, and the conviction, in concordance with that statement, that the "computer must not remain simply a tool for the simulation of what exists in a new form. It should not be used to paint in the way Piet Mondrian did or to compose music as Ludwig van Beethoven did. The computer gives us a new substance, it uncovers a new world before our eyes. In that world after so long a time scientists and artists will meet again on common ground, stimulated by their common desire for knowledge.’[9]

The reference to Mondrian was a critique of A. Michael Noll's experiment with a computer-generated Mondrian-like drawing.

\section{THE "GALOIS FIELD"}

The "Galois field," named after the French mathematician Évariste Galois (1811-1832), who outlined group theory, was a source of general inspiration to Bonačić. In abstract 


\section{CAT 2010 London Conference $\sim 3^{\text {rd }}$ February \\ Darko Fritz}

algebra, finite fields are known as Galois fields, and Bonačić studied them in connection with his work on the roots of polynomial equations. First in his scholarly work, but then also in the artistic, Bonačić developed his own, original method of studying the Galois field, in the way that he visualized it. In his article "Kinetic Art: Application of Abstract Algebra to Objects with Computer-Controlled Flashing Lights and Sound Combinations" (1974) he noted: "One of the most interesting aspects of this work [on Galois fields] is the demonstration of the different visual appearance of the patterns resulting from the polynomials that had not been noted before by mathematicians who have studied Galois fields."[10]

In 1969, using the PDP-8 computer, Bonačić created ten photographic works with oscilloscope screenshots the title of which contains the letters "PLN." In their name, those five works contain the exact algebra of the Galois field shown by the picture, e.g., IR.PLNS.0044.7714.7554.7744, whereby "IR" means irreducible (indivisible), "PLN" polynomial, "S" symmetry, and the numbers are linked with the polynomial properties. Bonačić described this work in the exact language of mathematics, as a "successive depiction of generating a maximal period in four irreducible polynomials of the tenth degree, $x 10+x 3+1$ (0044), 7714, 7554, 7744.’[11]

In the visualization of algebra of the Galois field, the calculated algebraic result can be shown in both symmetrical and asymmetrical visual compositions. In the description of the work RS.PLNS.0374.1024.0064 which depicts a two-dimensional polynomial of tenth degree, depending on the starting number, Bonačić has written a note that the shown case features "a rare symmetrical structure in a polynomial of tenth degree (it can not be expressed by means of the existing mathematical apparatus) 0374, 1024, 0064. Symmetry cannot be disrupted by a change of starting number." [12] Photographic reproductions show a sharp image of points projected onto the screen of the oscilloscope. In the series of works marked as "PLN," visual representations of Galois fields were used, where visualized numeric combinations, of which there are thousands or millions, depending on the degree of polynomials, are shown within fields (rasters) of $16 \times 16,32 \times 32$, or $64 \times 64$ elements. Because of the limited size of the oscilloscope screen, some works where photographed and then collaged together with other screenshots into a larger format by hand. In this way, a higher "resolution" was achieved, which means that the number of depicted elements was increased. In the mentioned work, IR.PLNS.0044.7714.7554.7744, the collage was made out of 28 photographs of the oscilloscope screen, which enables simultaneous insight into different stages of visualized algebra.

Bonačić's entire work is characterized by an innovative and creative approach, as well as an examination of the possibilities of standardized peripheral units (outputs) that show the final result of the work on the one hand, and the usage of personally created or adapted hardware on the other. 


\section{CAT 2010 London Conference $\sim 3^{\text {rd }}$ February \\ Darko Fritz}

The next five photographs from the series of works with "PLN" markings have no numerical descriptions of the applied polynomials, but they are presented only under the title PLN with added numbers 5-9, derived from the sequence of altogether fifteen exhibits displayed at Tendencije 4 in 1969. PLN 5, PLN 6, PLN 7, PLN 8 and PLN 9 differ from other PLN series works in the way that they do not show sharp contours of points "frozen" in the screenshot. In this series, there is no collaging of photographs, there is only one photograph of the whole screen, so that all the photographs are developed according to one rectangular frame from a $6 \times 6$ square of the photographic negative.

The works PLN 5-9 resemble experiments with photo focus and exposure time, but they have been obtained by creative usage of hardware and software parameters, which led to a new dimension in depicting static elements and their spatial relations. The works PLN 5, PLN 6, PLN 7, and PLN 9 look like a photograph in their long exposure time, where the shown elements no longer have a sharp outline. Because of the technical specificity of these works, collaboration with Marija Braut, that time's photographer at the Galerija suvremene umjetnosti, was established. Five works selected to be displayed at the exhibition Tendencije 4, later titled PLN 5, PLN 6, PLN 7, and PLN 9, had been chosen from a large quantity of photographic material.

\section{DYNAMIC OBJECTS}

Bonačic further elaborated the dimension of time, achieved through the combination of technologies of computer-generated images and the medium of photography in the described works, in a series of computer-generated light objects and installations which he named "dynamic objects". All Bonačić's dynamic objects contain the possibility of interaction with time dynamics, in the way that viewers (users) are enabled to control the rhythm of images or stop them.

From 1969 to 1971, Bonačić created a series of Bonačić's dynamic objects consisting of different computer-programmed light patterns displayed on originally designed panel made of metal tubes of different shapes and sizes. For all dynamic objects Bonačić made use of the "pseudorandom" algebra of Galois fields (see "GF" in the title of work). It was programmed on a SDS 930 computer in Real-Time FORTRAN, allowing direct usage of Assembler too, thus having an excellent tool for various bit manipulation techniques.[13] The software co-programmer was Miroljub Cimerman.[14] Bonačić used custom-made hardware for all his dynamic objects, that were produced or assembled of electronic components by himself and experts at the Ruđer Bošković Institute. They were embodied statements of what he later elaborated in his critique of the influence on the computer-based arts of commercially available display equipment. [15] In his 1974 article "Kinetic Art", Bonačić emphasized that this was "akin to an 


\section{CAT 2010 London Conference $\sim 3^{\text {rd }}$ February \\ Darko Fritz}

artist being limited to the use of only two or three colours in a painting. It is true that much can be done with such equipment but one can hope that ways will be found to take better advantage of computers.'[16]

In 1987, almost twenty years after his first artistic experiments, Bonačić explained that a dynamic object was a "sculpture and the concept in art in which impregnable unity is established between the computer system and the work of art."[17] In 1987 he added: "To integrate computer systems and art, without allowing one to dominate the other, is seen as a step toward the common language. This means that the artist and their work of art are able to communicate; artists and their art use a common language."[18]

The dynamic object GF.E 32-S (1969-1970) generates consecutive Galois field elements at maximal distance from each other and displays them as symmetrical patterns by synchronous selective flashing on the front panel of the object. It resembles a screen made of a $32 \times 32$ grid of squared aluminum tubes containing light bulbs. The total "screen resolution" is made of 1,024 monochrome "pixels." The Galois field generator is part of a special-purpose computer located inside the object. The unit is self-contained.

The clock that controls the rhythm of the appearance of the visual patterns is variable. The rhythm can be adjusted between 0.1 seconds and 5 seconds by the observer. At a frequency range of 2 seconds, the same pattern will repeat itself in approximately 274 years. On the rear of the object, the observer finds "manual controls to start, stop, control the speed and for selecting or reading out any of the patterns. With the binary notation, 32 light indicators and 32 push buttons enable any pattern from the sequence to be read or set."[19]

From a contemporary perspective, Bonačić's dynamic objects are a pioneering example of use of interactivity in computer-based art. As many other artworks made within the New Tendencies context[20], dynamic objects by Bonačić are designed both as artworks that can be experienced aesthetically and instruments or tools for visual research. Especially the latter aspect could lead us to the cognitive process (visual learning of mathematics and its hidden lows), a quality mentioned by Bonačić while describing his art production. [21]. All dynamic objects were made to be manipulated either by author (or someone from his team) or by the observer. Such experimentation and visual research (in the literal sense of the term) can be done within the controlled environment of an artist's or scientist's studio or laboratory by assistance of the artist or his collaborators, or by gallery visitors.

The front panel of the dynamic object DIN. GF 100 (1969) is made of a 16 x 16 matrix of luminous elements in 16 different colors, each one appearing 16 times. By using the Galois field generator, DIN GF 100 can produce 65,535 different pictures or 


\section{CAT 2010 London Conference $\sim 3^{\text {rd }}$ February \\ Darko Fritz}

patterns.[22] Depending on the decision of the user or observer, the image changes according to the clock every 200 milliseconds or 2 seconds, introducing the observer into a pseudorandom process. The object can be set in both "auto run" mode and interactive mode [23], as it was exhibited with remote control at the Tendencije 4 exhibition 1969. The observer can manipulate the light patterns by both the control panel that is at the back of the object and the remote control that is connected to the object by a four-meter long wire, a long enough distance for experiencing immediate interaction while observing the object from a larger distance. The controllers make possible to manipulate the sequence's speed rate and to switch on manually operation of the sequences step by step, including the freezing of the chosen pattern. [24]

Bonačić introduced a higher level of interactivity in the dynamic object GF. E $(16,4)$ that was conceived, developed, and built in Zagreb from 1969 to 1971.[25] It is $187 \mathrm{x}$ $187 \times 30 \mathrm{~cm}$ in size and half a ton in weight. The front panel shows a relief structure made of 1,024 light fields in 16 colors. Several Galois field generators operate in order to light the grid in different patterns and to produce the sound played through four loudspeakers, which create a quadraphonic sound system within the installation space. The field of the interaction extends from the sole object. The researcher/user/observer can influence both sound and image by using tenths of various knobs and switches at the (custom-made) special-purpose computer that is placed next to the object. Sound can be manipulated by the exclusion of some tones. The speed of the visual display can be adjusted as well by looping the selected sequences. A remote (radio) control is at the disposal of the viewer to manipulate some basic features. Yet, the observer cannot change the logic.

The entire "composition" of this audio-visual spectacle, which consists of 1,048,576 different visual patterns and 64 independent sound oscillators, can be played within 6 seconds or with a duration of 24 days.[26]

The bcd - cybernetic art team was founded in 1971, consisting of Bonačić, the software designer Miroljub Cimerman, his colleague from Ruđer Bošković Institute, and his wife, the architect Dunja Donassy. They would work together until Bonačić's death in 1999. bed cybernetic art team continued to develop the dynamic object GF.E $(16,4)$ over a number of years and experimented with different forms of external hardware. It was an instrument that changed interface design not only by taking up the newest technical possibilities that were rapidly changing between 1969 and 1974, but also by developing original new solutions.

Between 1972 and 1974 several upgrades that extended the interactivity level of GF.E $(16,4)$ were created by using an external computer and a light pen: the computer offered a new interface - an interactive monitor - and the light pen enabled a more intuitive interaction with its graphic interface. The object was also connected to standard 


\section{CAT 2010 London Conference $\sim 3^{\text {rd }}$ February \\ Darko Fritz}

computer industry hardware as the GT40 graphic terminal with printer, but the use of human brainwave activity was also considered as possible interface of interaction. Both the object's calm audio-visual output and the transcendental quality of the cognitive and bodily experience of higher mathematics led to its setup in St. Kilian church in Wiesbaden, Germany, from 1983 to 1985, "where it helps the Franciscans to prepare for mediation."'[27]

\section{ART INSTALLATIONS IN PUBLIC SPACE}

Bonačić also developed computer-based light installations for the public space that enabled another kind of interaction: an interaction at the social level. As part of the Tendencije 4 exhibition in 1969, he set up the large-scale dynamic object DIN. PR 18 on the facade of the Nama department store on Kvaternik Square in Zagreb. The 36 meter-long installation consisted of 18 elements; each element had a 3 x 5 grid light matrix. The installation performed a light show that flickered 262,143 patterns of the irreducible 18th-degree polynomial $(\mathrm{x} 18+\mathrm{x} 5+\mathrm{x} 2+\mathrm{x}+1)$. [28] The clock was adjusted at 200 milliseconds, but there was a possibility to adjust it to different rates "upon the border of the perception of the observer and frequency clock."[29]

At that time, the square was rather dark, with little public lighting, so the installation also acted as additional illumination. In July 1969 art critic and curator Želimir Koščević published in the daily newspaper Telegram an affirmative evaluation of the "message" of this public light system, used for an aesthetic rather than a commercial purpose, as opposed to the lit signs of companies that had started to appear in Zagreb's city center.[30] Koščević also found that this public installation showed a refinement of the idea of democratization of art within the context of the NT movement. He observes that Bonačić, "with his ideas, is a part of the front that within the 'Tendencies' movement attempts to open a path for art that would simply be work, the results of which will be meant for everyone, without the obligation to take our hats off and buy an entrance ticket for the unavoidable museum or gallery before we face it. Tomorrow is, as it seems, meant for just that kind of art."'[31]

In 1971, the installation DIN.PR 18 was replaced by a more complex installation, DIN.PR 16, set at in the same place, at the top of the facade, but now in the form of a triple frieze of light elements. An additional spatial extension was made by new light elements set in the continuation of the freeze on the other side of the building, as well as into the indentation of the front.

A year before in 1970, another dynamic object was set up in the facade of the Muzej savremene umjetnosti Beograd [Museum of Contemporary Art] for the 4. Trijenale jugoslavenske likovne umetnosti [4th Triennial of Yugoslavian Art] in Belgrade, [32]. When Bonačić replaced the installation at Nama in 1971, he also set up a another installation on facade of the Nama department store on Ilica street, the dynamic object 


\section{CAT 2010 London Conference $\sim 3^{\text {rd }}$ February \\ Darko Fritz}

DIN.PR 10. Finally, another dynamic object was exhibited only several hundred meters further at the facade of the Kreditna banka Zagreb building on Ban Josip Jelačić square in Zagreb. None of the "outdoor" works mentioned that were set up in public spaces are still in place, nor are their original elements traceable at a moment. At least, however, all of Bonačić's "in door" dynamic objects still exist and are in good condition; [33] they belong to the small group of computer-generated interactive objects from the 1960s that are still functioning today.

\section{CRITIQUE OF TRUE RANDOMNESS IN COMPUTER ART}

"I am especially sceptical of the attempts to produce computer art through play with randomness and the deliberate introduction of errors in programs prepared for nonartistic purposes,' [34] wrote Bonačić in 1974. He supported art practices where, like in his dynamic objects that make use of pseudorandomness, the "feedback loop might be closed with an aesthetic output to an art object, which would then provide semantically relevant information to a viewer. I believe that such interactions will add to cognition, which will be reflected in language and perhaps provide improved means of communication.’[35]

In his paper from 1969, he discussed the notions of information and entropy, redundancy and originality in the writings of George David Birkhoff, Max Bense, and Abraham A. Moles: "Observing the qualitative relation for the aesthetic measure, we come to conclude that the maximal originality (namely, disorder created by random selection of symbols) brings immense aesthetic values. Let us suppose we have created the program in some other way; but still it is the program that will result in an aesthetic object. Using the random generator, we shall carry on with random distribution of the existent information. While consistent in use of the random generator, we speak of 'maximal originality,' no matter what the results of the program might be. The random generator creates the accidental and unique presentation, which has neither value nor importance for human beings. Such information can evoke various associations in the observer. But a computer used in such a way lags far behind the human being. Even if the expressive potentialities of the computer were equal to those of a human being, the essence of Pollock's world and creation would not be surpassed, regardless of the complexity of future computers or peripheral units. That, of course, does not mean that a man (or a monkey or other animal) aided by a computer could not create an aesthetically relevant object if they consciously or unconsciously act obeying the law of accident."[36]

This critique inspired the creation of the object Random 63 (1969), making use of 63 independent true random generators; each of them caused the activation of an electric lamp. The geometric pattern of the placement of the light bulbs at the object's front was calculated with a PDP-8 computer using the pseudorandomness of the Galois fields. 


\section{CAT 2010 London Conference $\sim 3^{\text {rd }}$ February \\ Darko Fritz}

This is the only dynamic object by Vladimir Bonačić that makes use of true randomness for the dynamic control of the lights.

In his paper "Computer Graphics and Visual Art," published in bit international 2 in 1968, German computer art pioneer Georg Nees asked: "Shouldn't information aesthetics be able to use certain modeling techniques? The information it should model is aesthetic information, such as appears in nature and art. However, the dependency of aesthetic information on processes should be modeled as well, while conceiving the processes themselves as temporarily dependent information."[37]

Similar ideas are found in writings by Jonathan Benthall, who participated in two Tendencies conferences and observed: "Max Bense writes that mathematical aesthetics is a process which is 'devoid of subjective interpretation and deals objectively with specific elements of the 'aesthetic state' of as one might say the specific elements of the 'aesthetic reality.' These elements include meanings as well as sensuous or formal qualities. Bense proposes a 'generic aesthetics' which would explain how aesthetic states are generated in the same way as generative grammar in linguistics attempts to explain the logical processes by which sentences are performed and interpreted; but a prior stage of analytical aesthetics is held to be necessary. The main mathematical techniques proposed by Bense are semiotic (the study of signs, originated by Charles Sanders Peirce and others), metrical (concerned with forms, figures and structures), statistical (concerned with the probability of appearance of elements), and topological (concerned with the relations between sets of elements)."[38] Benthall continues: "Vladimir Bonačić is sceptical about the applicability of information theory to aesthetics, since it takes so little account of semantics. But he approaches visual phenomena in a mathematical and systematic way.'[39]

\section{BONAČIĆ'S DEVELOPMENT AFTER 1972}

Contradicting Bonačić's wishes of 1968 that computer art should not mimic humanmade images, computer-generated art pursued a different path. Computer graphics explored the possibilities of computer-generated figurative visuals and entered - with the provision of animation and special effects for the mainstream film industry - the commercial world, as well as the military sector, advancing virtual-reality techniques that mimic "real life." This development, within the context of the dominance of emerging practices of conceptual and non-object art that utilized post-Duchamp ideas of art and representation, led to computer-generated art's almost total exclusion from the contemporary art scene by the mid-1970s. This development was propelled by a rising anti-computer sentiment among the majority of the new generation of artists, in view of the negative impact of the use of science and technology by the military-academiccorporate complex in the Vietnam War and elsewhere.[40] 
CAT 2010 London Conference $\sim 3^{\text {rd }}$ February

Darko Fritz

Bonačić was one of the rare artists who found and constantly reinvented a way to use computers and cybernetic art for humanistic purposes. After the period of the first series of dynamic objects, Bonačić's work from 1971 emerged within the bcd - cybernetic art team.

In 1972, Bonačić and the bed cybernetic art team moved to Israel and founded in 1973 the "Jerusalem Program in Art and Science," an interdisciplinary program for study and research at the Bezalel Academy of Arts and Design in Jerusalem, which he directed until 1977. For this program he established collaborations with the Hebrew University of Jerusalem and the Israel Museum. In 1974, he organized an international seminar on "The Interaction of Art and Science," in which several New Tendencies protagonists, such as Jonathan Benthall, Herbert W. Franke, Frank Joseph Malina, Abraham A. Moles, A. Michael Noll, and John Whitney, participated. In 1975, Willem Sandberg, a Dutch typographer and director of the Stedelijk Museum, received the Erasmus Prize in Amsterdam. On Sandberg's recommendation, half of the prize was dedicated to "The Jerusalem Program in Art and Science."

The "Art and Science team" that included alongside others Willem Sandberg and the bcd cybernetic art team were approached by Radoslav Putar to propose one of the exhibitions for Tendencije 6. [41] Many members participated, and some disappointedly left the organizational board of Tendencije 6 [42] that over the five years searched for appropriate concepts for follow up New Tendencies, discussing many different options ranging form Naïve art to socially engaged video communities. The Art and Science team, represented by Bonačić, proposed the exhibition Meta Language in Development of Computer Art [43]. Finally, Tendencije 6 started with the conference Umjetnost $i$ društvo/ Art and Society in 1978 in Zagreb, but the planned exhibition(s) never took place. The conference was the very last manifestation of New Tendencies. As the focus had shifted to video, Conceptual, and non-object art, next to the conference, a different exhibition was shown presenting Conceptual art from Yugoslavia only, entitled Nova umjetnička praksa [New Art Practice] (local synonym for conceptual and body art and related practices). Bonačić participated at the conference with the paper "Čovjek-jezikmaterija ili dematerijalizacija umjetnosti" / "Man, Language, Matter - The Dematerialization of Art" [44] that discussed "an operational relationship between matter and thought," but also the relationship of a Darwinian evolution model and artificial intelligence along other subjects. He concluded his paper with the following thought: "The establishment of a common denominator would lead to a greater probability of an ethical evolution and thus, the creation of a new paradigm for society.'[45] 
CAT 2010 London Conference $\sim 3^{\text {rd }}$ February

Darko Fritz

\section{CONCLUSION: TEMPORARILY REALIZED NEW TENDENCIES}

From the beginning of his artistic activity, the work of Vladimir Bonačić was drawing the attention not only of his colleagues who participated in a part of the program Computers and Visual Research but also of the older generation of New Tendencies participants.

At the Tendencije 4 exhibition in 1969, Bonačić showed a total of 15 works in the gallery, as well as the outdoor installation DIN.PR 18, and for this participation he was awarded one of the prizes of the competition related to the exhibition.[46] The jury, consisting of Umberto Eco, Karl Gerstner, Vera Horvat-Pintarić, Boris Kelemen, and Martin Krampen, appreciated "the harmony between the mathematical consequences within the programming and the visualizing of the process resulting from the programming. We praise especially Bonačić's new approach entailing the solving of problems by including a picture and not a number as a parameter, rendering possible thereby the solution of much more complicated problems."'[47]

The statement of Brazilian artist Waldemar Cordeiro for the Tendencije 5 conference that " $[\mathrm{t}]$ he Constructive art belongs to the past, its contents corresponding to the Paleocybernetic Period being those of computer art,"[48] i.e., that computer art had replaced Constructivist art, found its proof in Bonačić's artwork. What's more, probably with his dynamic objects, especially the ones set in public space, Bonačić managed to make real the utopia outlined by Matko Meštrović and other New Tendencies theoreticians by the beginning of the 1960s. His work is exact research leading to cognitive insights. Science has been humanized, and art has been scientificalized. Works have been realized through the use of machines, and their basic materials were time and light. They refer to the viewer as an active participant, sometimes in physical interaction with dynamic objects, and they are both socially engaged and democratic. It is possible to multiply the works by programming purpose-targeted software and constructing hardware.

It seems that Bonačić's work fulfilled and propelled Meštrović's visions from 1963 introduced at the beginning of the text, summarized in idea that "in order to enrich that which is human, art must start to penetrate the extra-poetic and the extra-human."[49] Bonačić's work has, at least temporarily, realized the program of the New Tendencies that at a certain point of time looked utopian. However, today it is being reactualized in a new geopolitical, technological, and cultural climate.

References

[1] VLADIMIR BONAČIĆ, Pseudo-slučajna transformacija podataka u asocijativnoj analizi kompjuterom, Ph.D. thesis, Faculty of Electrical Engineering, University of Zagreb, Zagreb, 1968. 


\section{CAT 2010 London Conference $\sim 3^{\text {rd }}$ February \\ Darko Fritz}

[2] FRANÇOIS MORELLET, untitled, in: Nove Tendencije, exhib. cat., Galerija suvremene umjetnosti, Zagreb, 1961

[3] MATKO MEŠTROVIĆ, "Ideologija novih tendencija" [The Ideology of the New Tendencies] in Od pojedinačnog općem [From Particular to General], Mladost, Zagreb, 1967, and DAF, Zagreb, 2005.

[4] MATKO MEŠTROVIĆ, untitled, in: Nove Tendencije 2, exhib. cat., Galerija suvremene umjetnosti, Zagreb, 1963, n. p. see the essay by Matko Meštrović, "Scientifikacija kao uvjet humanizacije" ["Rendering Scientific as the Condition for Humanization"], in: idem, Od pojedinačnog općem, Mladost, Zagreb, 1967, pp. 221-230.

[5] MATKO MEŠTROVIĆ, untitled, in: Nove Tendencije 2, exhib. cat., Galerija suvremene umjetnosti, Zagreb, 1963, n. p.

[6] Statement at the symposium "Kompjuteri i vizuelna istraživanja" [Computers and Visual Research], May 6, 1969, Kulturno informativni centar (KIC), Zagreb, audio recording, MSU Zagreb Archives, transcribed and translated by the author. Translated from the Croatian.

[7] RADOSLAV PUTAR, untitled, Tendencije 4, 1970, exhib. cat., Galerija suvremene umjetnosti, Zagreb, 1970.

[8] VLADIMIR BONAČIĆ, "Mogućnosti kompjutera u vizualnim istraživanjima" / "Possibilities for Computer Applications in Visual Research," in: bit international 3, Boris Kelemen and Radoslav Putar (eds.), Galerije grada Zagreba, Zagreb, 1971, pp. 45-58; Vladimir Bonačić, "Umjetnost kao funkcija subjekta" / "Arts as Function of Subject, Cognition, and Time," in: bit international 7, Boris Kelemen and Radoslav Putar (eds.), Galerije grada Zagreba, Zagreb, 1971, pp. 129-142.

[9] BONAČIĆ, "Mogućnosti kompjutera u vizualnim istraživanjima"/ "Possibilities for Computer Applications in Visual Research," 1971, p. 58. Translated from the Croatian.

[10] VLADIMIR BONAČIĆ, "Kinetic Art: Application of Abstract Algebra to Objects with ComputerControlled Flashing Lights and Sound Combinations," Leonardo, vol. 7, no. 3, 1974, p. 253-260.

[11] VLADIMIR BONAČIĆ, “Exhibits in the context of Tendency 4, Zagreb May 1969”, text of explanatory plaques for Tendencies 4 exhibition, p. 2, Archive MSU Zagreb.

[12] ibid, p.3

[13] Personal communication of the author with Miroljub Cimerman.

[14] Miroljub Cimerman was collaborating with Vladimir Bonačić at the Ruđer Bošković Institute from 1967.

[15] Bonačić 1974, p. 253.

[16] Bonačić 1974, p. 253.

[17] VLADIMIR BONAČIĆ, “On the boundary between science and art," in: Impact of Science on Society, vol. 27, no. 1, January/March 1977, p. 25.

[18] VLADIMIR BONAČIĆ, “A Transcendental Concept for Cybernetic Art in the 21st Century,” in: Visions for Cybernetic Art, exhib. cat., Paris Art Center, Académie Européenne des sciences, des arts et des letters, Paris, 1987, n. p. 


\section{CAT 2010 London Conference $\sim 3^{\text {rd }}$ February \\ Darko Fritz}

[19] Bonačić 1974, p. 255.

[20] For example, Reljefometar [Relief-Meter](1964-1967) by Vjenceslav Richter, manipulable lumino-kinetic works by the group MID, or Un instrument visuel (1965) by Michel Fadat, all exhibited at New Tendencies exhibitions.

[21] BONAČIĆ, "Umjetnost kao funkcija subjekta spoznaje i vremena" / "Arts as Function of Subject, Cognition, and Time," paper read at the symposium Computers and Visual Research, Zagreb, 5-6 May 1969 , published in Bit International, No. 7, "Dialogue with the Machine” (1971) pp. 129-142.

[22] Tendencije 4, 1970, exhib. cat., Galerija suvremene umjetnosti, Zagreb, 1970., n.p.

[23] ibid.

[24] ibid.

[25] This computer sculpture was first exhibited 1971 at the 7th Biennale in Paris in the section "Interventions" at Parc Floral, Bois de Vincennes from 24th September until 1st November 1971, followed by display at the UNESCO building in Paris, on the occasion of the 25th anniversary of the UNESCO from November 1971 until November 1972.

[26] In his Leonardo article, Bonačić elaborates these different kinds of interaction from a practical and theoretical point of view and also considers the use of brainwaves in art practice. See: Bonačić 1974, pp. $195 f$.

[27] RAYMOND DAUDEL, “The Cybernetic Art of the bcd Team,” in: Visions for Cybernetic Art, exhib. cat., Paris Art Center, Académie Européenne des sciences, des arts et des lettres, Paris, 1987, n. p.

[28] VLADIMIR BONAČIĆ, "Eksponati u okviru tendencija 4 Zagreb maj 1969." / Exhibits within tendencies 4, Zagreb May 1969", text of explanatory plaques for Tendencies 4 exhibition, p. 3 and 4, Archive MSU Zagreb.

[29] ibid, p. 4

[30] ŽELIMIR KOŠČEVIĆ, “Svjetlost nove urbane kulture,” in: Telegram, 479, July 4, 1969, p. 17. Translated from the Croatian.

[31] Ibid. Translated from the Croatian.

[32] 4. trijenale jugoslovenske likovne umetnosti, Muzej savremene umjetnosti, Belgrade, 3rd July until 15th September 1970; curator: Jerko Denegri.

[33] In total, eight electronic dynamic objects were presented at the bit international exhibition: seven objects at Neue Galerie in Graz, 2007, and three at the ZKM | Center for Art and Media Karlsruhe, 2008/2009. Miroljub Cimerman, Dunja Donassy, and ZKM technicians restored GF. E /16,4 for the first public display since 1985.

[34] Bonačić 1974, p. 193.

[35] Ibid, p. 194.

[36] BONAČIĆ, "Umjetnost kao funkcija subjekta spoznaje i vremena" / "Arts as Function of Subject, Cognition and Time," 1971, p. 138. Translated from the Croatian. 


\section{CAT 2010 London Conference $\sim 3^{\text {rd }}$ February Darko Fritz}

[37] GEORG NEES, "Computergraphik und visuelle Komplexität" / "Kompjuterska grafika i vizuelna kompleksnost," in: bit international 2, Boris Kelemen and Radoslav Putar (eds.), Galerije grada Zagreba, Zagreb, 1968, p. 32.

[38] JONATHAN BENTHALL, Science and Technology in Art Today, Thames and Hudson, London, 1972, p. 59.

[39] Ibid., p. 62.

[40] Misuse of technology has been recently described by Richard Barbrook: "M.I.T. modernization theory would prove its [USA] superiority over the Maoist peasant revolution. [...] Since the information society was the next stage in human development, the convergence of media, telecommunications, and computing must be able to provide the technological fix for anti-imperialist nationalism in Vietnam." Richard Barbrook, Imaginary Futures, <www.imaginaryfutures.net>, 2005, pp. 177 and 182; and Pluto Press, London, 2007. See also Anne Collins Goodyear, "From Technophilia to Technophobia: The Impact of the Vietnam War on the Reception of 'Art and Technology," Leonardo - Volume 41, Number 2, pp. 169-173, MIT Press, 2008.

[41] RADOSLAV PUTAR, letter to Vladimir Bonačić, October 4, 1978, Archive Dunja Donassy

[42] Letter of resignation from Tendencies 6 Organizational Board by Želimir Koščević, Archive MSU Zagreb.

[43] Attachment with the letter to Radoslav Putar "Proposal for the Exhibition Meta Language in Development of Computer Art" by Art and Science team, Zagreb, January 16, 1978, and related statement and specification by Vladimir Bonačić, January 22, 1978, both MSU Zagreb Archive. Translated from the Croatian.

[44] VLADIMIR BONAČIĆ, “Čovjek-jezik-materija ili dematerijalizacija umjetnosti” / "Man, Language, Matter - The Dematerialization of Art", paper read at the symposium Umjetnost i društvo/ Art and Society, Zagreb, 1978, MSU Zagreb Archive.

An extended version of this text, titled "Dematerialization of Art - A Heuristic Viewpoint," was presented at the symposium at the Ars Electronica 1979 in Linz. Symposium "Der modulierte Mensch," Ars Electonica, Internationales Brucknerfest, Linz, September 18-21, 1979, Linz, Austria.

[45] ibid.

[46] Bonačić received the prize together with Marc Adrian and the group Compos 68. See: "Computers and Visual Research, Decision of the Competition Jury," in: Tendencije 4, exhib. cat., Galerija suvremene umjetnosti, Zagreb, 1970, n. p.

[47] Ibid.

[48] WALDEMAR CORDEIRO, "Analogical and/or Digital Art," symposium t-5 [Tendencije 5?], "The Rational and Irrational in Visual Research Today. Match of Ideas," June 2, 1973, symposium proceedings, Galerija suvremene umjetnosti, Zagreb, 1973, n. p.

[49] Matko Meštrović, untitled, in: Nove Tendencije 2, exhib. cat., Galerija suvremene umjetnosti, Zagreb, 1963, n. p.. Translated from the Croatian. 